\title{
Motivasi Pendatang ke Kota (Suatu Kajian Kebijakan Ekonomi Makro)
}

\author{
FATKHURAHMAN \\ Sekolah Tinggi Ilmu Ekonomi Riau (STIER) \\ Jln. HR. Subrantas 57 Panam Pekanbaru 28293 Telp. (0761) 63237 \\ E-mail : akbar_stier@yahoo.com
}

\begin{abstract}
The issue became an issue separate entrants to local governments, especially after the implementation of regional autonomy in areas where unemployment is already a responsibility of local governments. The macroeconomics of labor due to a lot of competition from the entry of migrants into a city, then the impact of competition, the impact of the use of natural resources is also a problem, the effects of pollution and other problems. The government needs to take a policy in order to control the immigrants for unemployment in urban areas can be suppressed. This study focused on areas particularly Pekanbaru Panam (Charming District), the aim is to find motivation immigrants and analyze factors that influence the motivation of migrants. The method used is descriptive method with quantitative analysis. Sources of data in this study are immigrants residing in the district Charming taken as many as 30 people using simple random sampling method. The results of this study indicate that: 1) It turns out that motivates immigrants to come to the city of Pekanbaru, especially areas Panam (Charming district) is due to cultural factors outside the region, followed by a factor of Pekanbaru city's rapid development, then as the security situation Pekanbaru city and also because the opportunity available work. 2) It turned out that employment opportunities can dampen the desire immigrants to come to the city of Pekanbaru (especially Panam region), because with the amount of employment opportunities, the competition to get a job will be very strict. This condition is not desired by the settlers with a capital of education and skills that all mediocre.
\end{abstract}

Keywords: Motivation, Immigrants, City.

Penelitian ini mengetengahkan persoalan tenaga kerja non lokal, dimana hasil penelitian terdahulu yang mengatakan bahwa dengan masuknya tenaga kerja non local ke Kota Pekanbaru menyebabkan terjadinya persaingan yang ketat dengan tenaga kerja tempatan sehingga terjadi banyak pihak yang memikirkan upaya ini seperti salah satunya adalah pemerintah daerah. (Fatkhurahman, 2008)

Pemerintah telah berupa melakukan pembatasan kesempatan kepada para pendatang untuk mengurungkan niatnya datang ke daerah ini, seperti dengan melakukan razia KTP dan ini dinilai dapat menghambat masuknya tenaga kerja non lokal dan mengurangi persaingan kerja dengan tenga kerja non lokal.

Kemudian juga pemerintah membuat kebijakan mengenai penempatan tenaga kerja lokal yaitu kebijakan kebijakan No. 4 Tahun 2002 tentang Penempatan Tenaga Kerja Lokal, dijelaskan bahwa tenaga kerja lokal memiliki porsi dalam pengisian lowongan pekerjaan yaitu lebih dari 50\% untuk 5 tahun pertama sedangkan untuk 5 tahun berikutnya mencapai $75 \%$.

Namun pada kenyataannya migrasi tenaga kerja untuk masuk ke kota Pekanbaru terus mengalami perkembangan, dimana data terakhir tahun 2008 menunjukkan jumlah penduduk kota Pekanbaru sebanyak 799.213 jiwa dan kecamatan Marpoyan damai merupakan kecamatan yang paling besar jumlah penduduknya $15,81 \%$ dan kecamatan Tampan sebanyak 12,72\% (BPS, 2009) dan perkembangan jumlah penduduk semenjak tahun 2004 hingga 2008 sebagai berikut: 
Tabel 1 Perkembangan Jumlah Penduduk Kota Pekanbaru Tahun 2004 2008

\begin{tabular}{ccc}
\hline Tahun & $\begin{array}{c}\text { Jumlah } \\
\text { penduduk }\end{array}$ & Perkembangan \\
\hline 2004 & 698.834 & \\
2005 & 720.197 & $3.1 \%$ \\
2006 & 754.467 & $4.8 \%$ \\
2007 & 779.899 & $3.4 \%$ \\
2008 & 799.213 & $2.5 \%$ \\
\hline
\end{tabular}

Sumber: Pekanbaru dalam Angka, 2009

Dari tabel 1 di atas dapat diketahui perkembangan penduduk kota Pekanbaru tahun 2004 - 2008 mencapai 3,4\% dimana perkembangan paling besar terjadi di tahun 2006 mencapai 4.8\%. Dari jumlah penduduk tersebut $51,55 \%$ diantaranya adalah berstatus bekerja, 8,55\% mencari pekerjaan, 3,49\% bersekolah, 7,19\% mengurus rumah tangga dan lainnya sebanyak 29,22\%.

Kondisi ini bila dibandingkan dengan kabupaten/kota lainnya seperti kota Dumai, Kabupaten Indragiri Hulu yang hanya berkisar $1-2 \%$ per tahun termasuk kota Pekanbaru cukup tinggi. Selain itu tingkat pendapatan perkapita masyarakat kota Pekanbaru yang relatif tinggi dimana pada tahun 2006 mencapai 21.849.958,66 meningkat pada tahun 2007 menjadi 25.797.448,81 dan meningkat lagi pada tahun 2008 menjadi 31.176.338,59 dan bila dibandingkan pendapatan perkapita regional tahun 2008 hanya 28.962.818,55 (BPS, 2009).

Gambar 1

Pendatang dengan Penduduk Tempatan Kota Pekanbaru Tahun 2009
Kondisi bencana alam yang terjadi di daerah sumatera barat dan sumatera utara (Nias) serta Aceh sehingga menyebabkan mereka mencari aman untuk pindah ke kota Pekanaru. Perpindahan tenaga kerja ini mencapai kisaran $60.8 \%$ dari perkembangan jumlah penduduk adalah pendatang.Penelitian ini memfokuskan lokasi di Kecamatan Tampan, dimana berdasarkan data di lapangan diketahui jumlah pendatang paling banyak bermukim di daerah ini. Hal ini untuk lebih jelasnya dapat dilihat pada tabel berikut ini:

$\begin{array}{rlr}\text { Tabel } 2: & \begin{array}{l}\text { Jumlah Kelahiran dan } \\ \text { Pendatang } \\ \text { kecamatan di Kota Pekanbaru } \\ \text { Tahun 2009 }\end{array}\end{array}$

\begin{tabular}{clcc}
\hline No & Kecamatan & $\begin{array}{c}\text { Kelahiran } \\
\text { (jiwa) }\end{array}$ & $\begin{array}{c}\text { Jumlah } \\
\text { Pendatang } \\
\text { (jiwa) }\end{array}$ \\
\hline 1 & Tampan & 2,815 & 3,526 \\
2 & Payung Sekaki & 63 & 1,130 \\
3 & Bukit Raya & 2,138 & 2,699 \\
4 & Marpoyan Damai & 4,078 & 3,405 \\
5 & Tenayan Raya & 1,381 & 1,381 \\
6 & Lima Puluh & 250 & 2,546 \\
7 & Sail & 96 & 146 \\
8 & Pekanbaru Kota & 104 & 629 \\
9 & Sukajadi & 102 & 1,865 \\
10 & Senapelan & 506 & 179 \\
11 & Rumbai & 323 & 474 \\
12 & Rumbai Pesisir & 491 & 1,201 \\
\hline & Jumlah & 12,347 & 19,181 \\
\hline
\end{tabular}

\section{Jumlah lahir +}

pendatang 31,528

\begin{tabular}{lll} 
Persentase & $\mathbf{3 9 . 2 \%}$ & $\mathbf{6 0 . 8 \%}$ \\
\hline
\end{tabular}

Sumber: Catatan Sipil dalam angka, data diolah 2010.

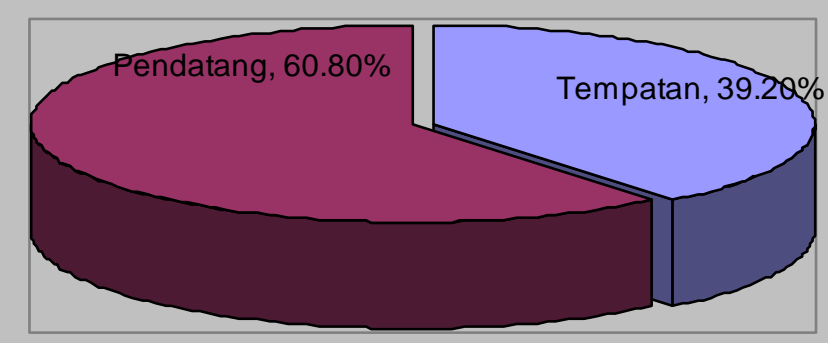

Sumber: Diolah dari berbagai sumber. 
Dari data pada tabel 2 di atas, dapat diketahui jumlah pendatang ke kota Pekanbaru pada tahun 2009 mencapai 19.181 jiwa dimana yang paling besar terdapat di kecamatan Tampan yang mencapai $18.4 \%$ dan paling kecil adalah pada kecamatan Sail yang hanya mencapai $0.8 \%$.

Fenomena pesatnya pembangunan kota Pekanbaru yang ditandai dengan pembangunan pusat bisnis, pusat pemerintahan, pusat pendidikan, pusat kesehatan serta pembangunan perumahan, pembangunan sarana olahraga dan lain sebagainya.

Kemudian juga ditambah dengan fenomena lokasi kota Pekanbaru yang strategis merupakan daerah yang berbatasan dengan negara tetangga Malaysia, jalur lintas antar kota antar propinsi.

Selain itu ditambah dengan fenomena kesempatan kerja yang tinggi dan tingkat upah minimum regional yang juga tinggi dan keamanan kota yang terjamin dibandingkan dengan daerah lainnya seperti Sumbar, Aceh, Medan dan daerah lainnya seperti Jawa dan kemudian fenomena budaya merantau yang membuat adanya fenomena pergi dan datang penduduk.

Berdasarkan latar belakang masalah tersebut di atas, maka dirumuskan masalah sebagai berikut: Apakah faktor pembangunan kota, lokasi kota, kesempatan kerja, situasi keamanan kota dan budaya merantau merupakan faktor yang mempengaruhi motivasi pendatang ke kota Pekanbaru, khususnya daerah panam?

Adapun tujuan yang ingin dicapai dalam penelitian ini adalah

1. Untuk mengetahui motivasi pendatang ke kota Pekanbaru khususnya daerah panam

2. Untuk mengetahui dan menganalisis pengaruh faktor pembangunan kota, lokasi kota, kesempatan kerja, situasi keamanan kota dan budaya merantau terhadap motivasi pendatang ke kota Pekanbaru khususnya daerah panam. Menurut teori pembangunan Denis Goulet yang dikutip dalam Todaro (2000) adalah perubahan yang menyeluruh yang meliputi usaha penyelarasan keseluruhan sistem sosial terhadap kebutuhan dasar dan keinginan-keinginan yang berbeda bagi setiap individu dan kelompok sosial dalam sistem tersebut, berpindah dari suatu kondisi yang dianggap sebagai tidak menyenangkan kepada kondisi yang menyenangkan yang dianggap "lebih baik" atau lebih berperikemanusaiaan secara material dan spiritual. Pembangunan berperikemanusiaan, dicapai melalui tiga inti, yaitu:

(1) Nafkah hidup yang diartikan dalam pemenuhan kesejahteraan individu yang sering diukur dalam bentuk pendapatan perkapita,

(2) Bebas dari perbudakan dan dapat memilih yang diartikan dalam pemenuhan kebutuhan pendidikan, kesehatan dan kualitas hidup secara umum, dan

(3) Harga diri (self esteem dan self respect).

Pembangunan menurut teori Lewis adalah pembangunan ditinjau dan diukur melalui kondisi perekonomian. Dimana perekonomian terkebelakang terdiri dari dua sektor: yaitu:

(1) sektor tradisional, yaitu sektor pedesaan subsistem yang kelebihan penduduk dan ditandai dengan produktivitas marjinal yang kerja sama dengan nol atau surplus tenaga kerja, ini disebabkan oleh penarikan sebagian tenaga kerja dari sektor pertanian dan sektor tersebut tidak akan kehilangan output sedikitpun; dan

(2) sektor industri perkotaan yang tingkat produktivitasnya tinggi menjadi tempat penampungan tenaga kerja yang ditransper sedikit demi sedikit dari sektor subsistem (pedesaan).

Menurut masyarakat akuntansi sumber daya alam dan lingkungan Indonesia 2002, bahwa sebagai salah satu prasyarat bagi terlaksananya pembangunan 
yang berkelanjutan adalah tersusunnya neraca sumber daya alam dan lingkungan.

Cushway dan Hodge yang diterjemahkan oleh Sularno Tjoptowardoyo (1992) mengatakan bahwa motivasi berkaitan dengan dorongan yang mempengaruhi perilaku setiap orang dalam organisasi dan tingkat komitmen yang ditujukan oleh para pegawai terhadap pencapaian sasaran dan tujuan organisasi.

Motif menurut Fremont dan Rossenwig yang diterjemahkan oleh Ali (1995) adalah apa yang menggerakkan seseorang untuk bertindak dengan cara tertentu atau sekurang-kurangnya mengembangkan suatu kecenderungan perilaku tertentu.

Dorongan untuk bertindak ini dapat dipicu oleh suatu rangsangan luar atau lahir dalam diri iru sendiri dalam proses psikologis dan pemikiran individu. Perbedaan motivasi niscaya merupakan faktor terpenting untuk memahami dan meramalkan perbedaan perilaku individual.

Motivasi dapat mempengaruhi perilaku seseorang dalam bekerja. Hal tersebut sesuai dengan pendapat Gibson, Ivancevich dan Donnely (1996) bahwa motivasi adalah konsep yang menjelaskan kekuatan yang berpengaruh pada atau di dalam diri seseorang yang menimbulkan dan mengarahkan perilaku.

Terry (1977) mendefinisikan motivasi sebagai keinginan dalam seorang individu yang mendorong ia untuk bertindak. Anoraga (2001) mengatakan bahwa motivasi kerja adalah suatu yang menimbulkan semangat atau dorongan kerja. Oleh sebab itu motivasi kerja dapat disebut sebagai pendorong semangat kerja.

Menurut Sulistiyani (2003) motivasi merupakan dorongan untuk melakukan sesuatu kegiatan. Dorongan ini memberikan dampak kepada hasil kerja yang dicapainya.

Menurut Ubaedy (2007) motivasi digambarkan seperti untuk menjadi orang yang kompeten di bidang apapun, syarat pertama yang harus dimiliki adalah punya gairah yang kuat. Kenapa? Kalau anda memotong kayu dengan pedang yang tajam tetapi gairah anda setengah-setengah, apa jadinya? Pasti lama.

Bahkan mungkin saja tidak berhasil. Begitu juga dengan keinginan anda untuk berprestasi. Meskipun anda punya pengetahuan yang bagus, punya skill yang bagus, punya fasilitas yang bagus, tetapi kalau gairah anda setengah-setengah, jadinya seperti contoh di atas. Selain pasti lama, ada kemungkinan untuk gagal.

Bukan begitu? Karena itu, anda melihat orang berprestasi di bidang apapun, di mana pun, dengan latar belakang apapun, pasti mereka mempunyai gairah yang kuat untuk berprestasi. Tidak ada orang berprestasi yang gairahnya setengahsetengah. Bahkan menurut para pejuang, peranan gairah ini jauh lebih menentukan ketimbang intelektual.

Teori motivasi yang dikemukakan oleh Vroom dalam Asnawi (2002) teori motivasia kerja yang dikenal dengan VIE mencakup valenci/kemampuan (valence), sarana (instrumentality) dan harapan (expectacy).

Valenci mengacu pada keinginan atau kemampuan yang menarik atau menolak dan memiliki sesuatu tertentu pada lingkungan kerja, uang misalnya memiliki valenci positif bagi kebanyakan orang, sementara kondisi kerja yang tidak aman memiliki valenci negatif.

Sarana,

bagaimana kemungkinanannya suatu hal yang potensial akan berimplikasi terhadap sesuatu yang bernilai lain, misalnya kinerja yang baik berimplikasi kepada promosi. Sarana didasarkan pada konsep path goal, yang merupakan hubungan yang dirasakan antara dua hasil.

Expectacy, bagaimana kemungkinan pekerja menyakini bahwa apa yang telah diusahakan itu akan membawa kepada kinerja yang baik.

Berdasarkan uraian di atas dapat dijelaskan bahwa motivasi adalah dorongan seseorang untuk melakukan suatu pekerjaan. Dimana dimensi motivasi adalah kemampuan, sarana dan harapan. 
Menurut Sulistiyani (2003) faktorfaktor dalam motivasi antara lain karena faktor intrinsik dan faktor ekstrinsik. Berangkat konsep tersebut, maka dapat disimpulkan bahwa motivasi tenaga kerja non lokal adalah dorongan yang dimiliki tenaga kerja pendatang untuk datang ke suatu daerah ke daerah tertentu. Apakah dorongan ini karena faktor intrinsik seperti keinginan merantau, karena ingin berubah atau karena faktor ekstrinsik seperti kebijakan dan kesuksesan serta lainnya.

Berdasarkan konsep teori di atas, dapat dibuat kerangka pemikiran dalam penelitian ini sebagai berikut: karena relatif banyaknya populasi maka ditetapkan sampel penelitian sebanyak 30 orang dari seluruh populasi diambil secara acak sederhan atau menggunakan simple random sampling. Data dikumpulkan dengan menggunakan: Kuesioner, kuesioner ditujukan kepada tenaga kerja pendatang berkenaan dengan motivasinya bekerja di Kota Pekanbaru.

Dokumentasi, yaitu dengan mengumpulkan data skunder seperti dari BPS dan Kantor Camat. Setelah data penelitian terkumpul,-

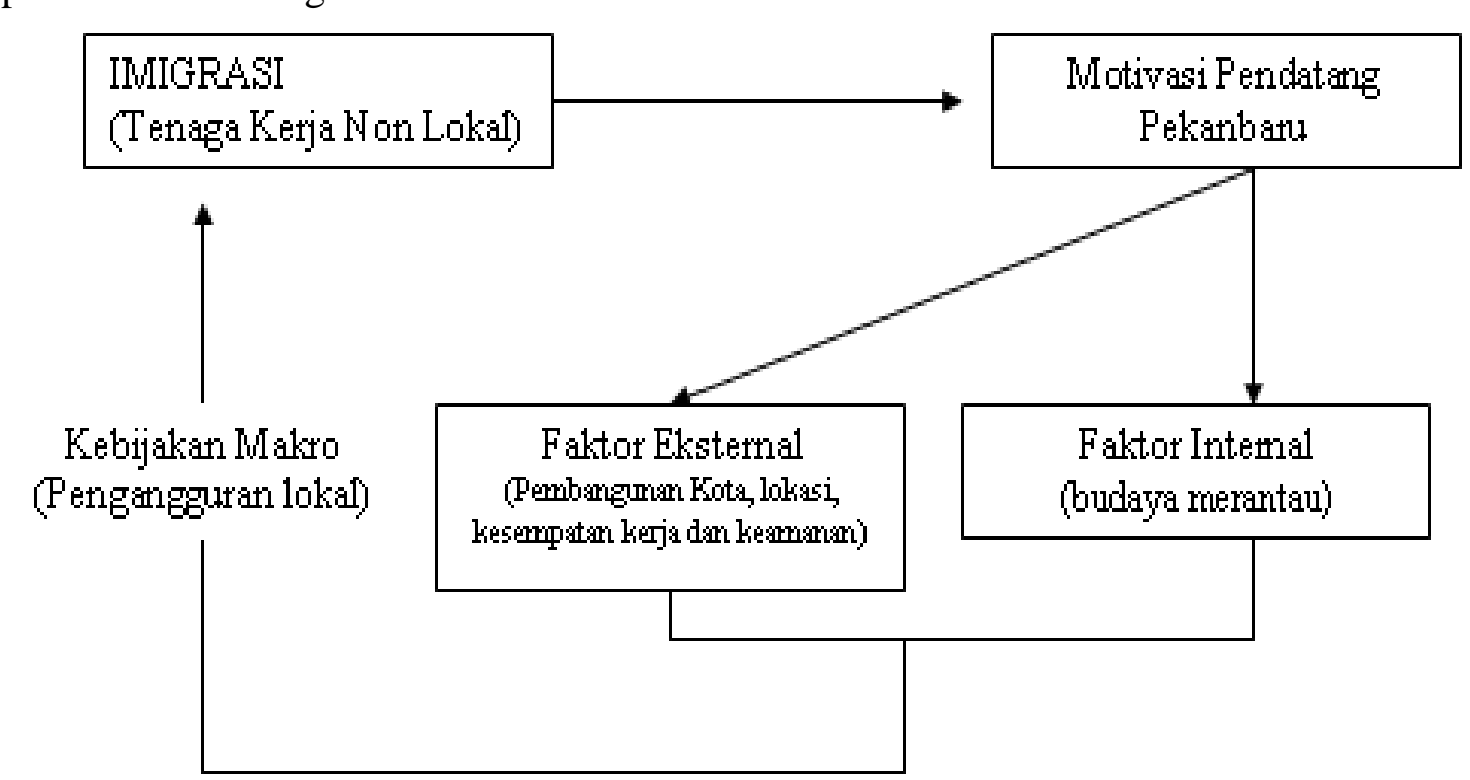

\section{METODE}

Jenis penelitian ini adalah penelitian survey dengan pendekatan desktiptif yaitu memberikan gambaran nyata apa adanya yang terjadi di lapangan mengenai alasan pendatang ke Pekanbaru khususnya daerah panam. Penelitian ini menggunakan jenis data primer dan data skunder. Data primer diperoleh melalui survey kepada para pendatang mengenai motivasinya ke Pekanbaru.

Sedangkan data skunder yang digunakan adalah data tentang kependudukan, dan ketenagakerjaan.

Populasi dalam penelitian ini adalah pendatang di Kecamatan Tampan/Panam Kota Pekanbaru yang berjumlah 3.526 jiwa yang tersebar di empat kelurahan. Oleh maka dilakukan analisis dengan menggunakan analisis desktiptif dengan memberikan gambaran apa adanya kondisi lapangan hasil penelitian.

\section{HASIL}

Pendatang adalah penduduk yang datang dari berbagai tempat misalnya dari desa, dari kota lain ke suatu tempat dengan maksud tertentu yang tidak lahir di Kota Pekanbaru namun ke kota Pekanbaru. Motivasi adalah dorongan yang dimiliki seseorang untuk melakukan suatu perbuatan tertentu, dalam penelitian ini adalah perbuatan pindah dari suatu tempat ke kota Pekanbaru.

Berikut ini hasil penelitian tentang motivasi pendatang, pembangunan kota 
menurut pendatang, lokasi kota Pekanbaru menurut pendatang, kesempatan kerja menurut pendatang, situasi keamanan kota dan budaya merantau pendatang sebagai berikut:

Gambar di tersebut diktehaui bahwa motivasi pendatang ke kota Pekanbaru dalam kategori tinggi (77\%). Hal ini menunjukkan bahwa pendatang memiliki semangat yang tinggi untuk datang ke kota Pekanbaru. Selain itu juga hasil penelitian tentang pembangunan kota Pekanbaru menurut pendatang adalah pesat (77\%), kemudian dilihat dari lokasi kota Pekanbaru menurut pendatang cukup strategis (77\%), kesempatan kerja yang ada di Kota Pekanbaru tinggi $(80 \%)$, situasi keamanan aman (60\%) dan budaya merantau yang dimilili pendatang wajib (77\%).
Observations 30

\begin{tabular}{lrcccc} 
ANOVA & \multicolumn{1}{c}{ Significance } \\
\hline & $d f$ & SS & MS & $F$ & $F$ \\
\hline Regression & 5 & 2.344 & 0.468 & 3.722 & 0.0123 \\
Residual & 24 & 3.022 & 0.125 & & \\
Total & 29 & 5.366 & & & \\
\hline
\end{tabular}

\begin{tabular}{lll}
\hline Intercept & 0.67290395 & 0.45017307 \\
Pembangunan kota $\left(\mathrm{X}_{1}\right)$ & 0.22607098 & 0.24111539 \\
Lokasi kota $\left(\mathrm{X}_{2}\right)$ & 0.00248859 & 0.98786572 \\
Kesempatan kerja $\left(\mathrm{X}_{3}\right)$ & -0.0690407 & 0.70197675 \\
Situasi keamanan kota $\left(\mathrm{X}_{4}\right)$ & 0.05612372 & 0.70710017 \\
Budaya merantau $\left(\mathrm{X}_{5}\right)$ & 0.54583161 & 0.00708383 \\
\hline
\end{tabular}

\section{Formula:}

$$
\begin{aligned}
& Y=0,673+0,226 X_{1}+0,002 X_{2}-0,069 \\
& X_{3}+0,056 X_{4}+0,546 X_{5}
\end{aligned}
$$

\section{Hasil Fenelitian}

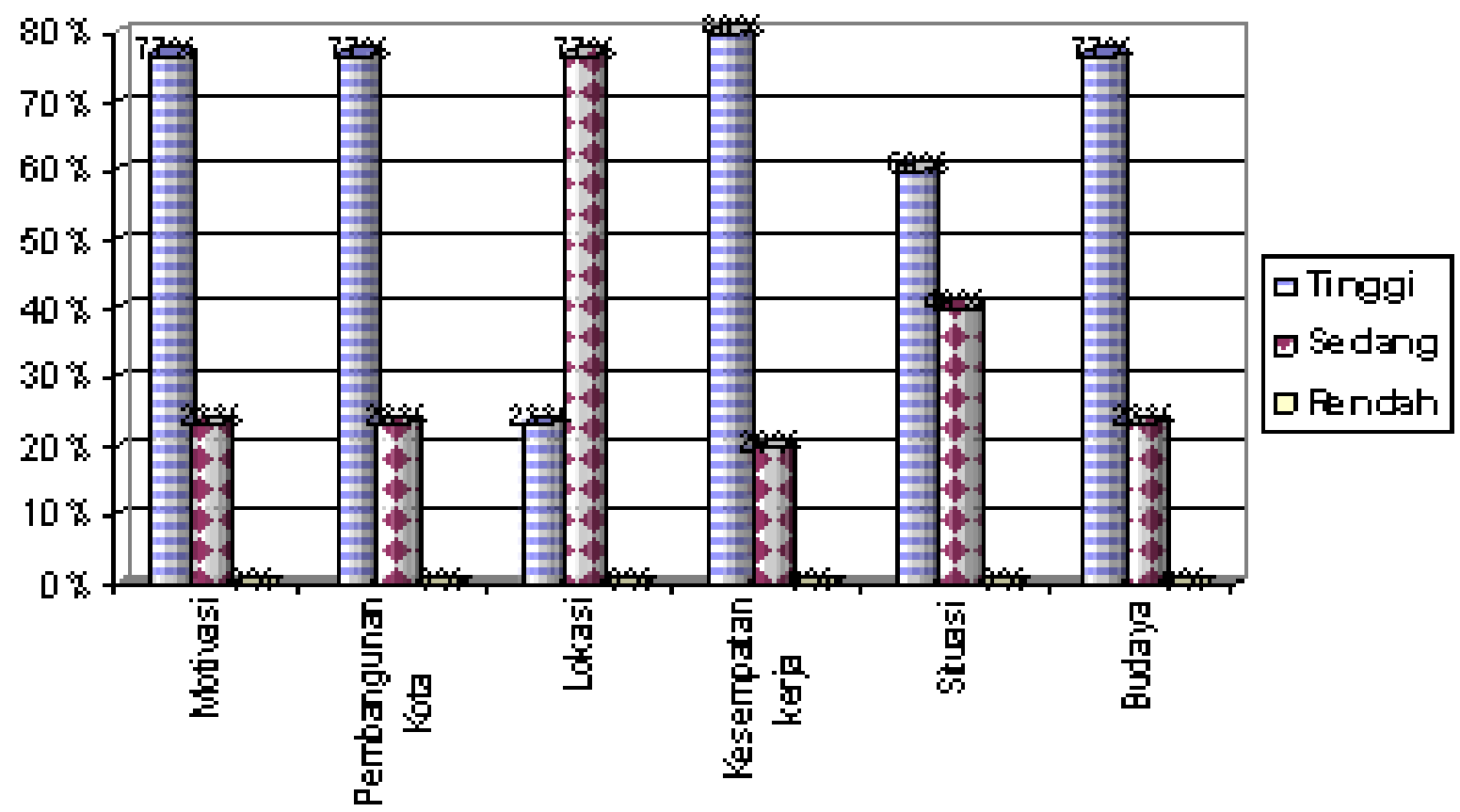

Kemudian hasil pengolahan data penelitian dengan regresi diperoleh hasil penelitian sebagai berikut:

\begin{tabular}{ll}
\hline \multicolumn{2}{c}{ Regression Statistics } \\
\hline Multiple R & 0.66089214 \\
R Square & 0.43677842 \\
Adjusted R Square & 0.31944059 \\
Standard Error & 0.35488393
\end{tabular}

\section{Ternyata:}

1. Faktor budaya merantau menjadi faktor yang berpengaruh signifikan mempengaruhi motivasi pendatang ke kota Pekanbaru $(0,007<0,05)$

2. Sedangkan faktor pembangunan kota $(0,241>0,05)$, faktor lokasi kota $(0,987>0,05)$, kesempatan 
kerja $(0,702>0,05)$ dan situasi keamanan kota $(0,707>0,05)$ memberikan pengaruh tidak signifikan terhadap motivasi pendatang untuk datang ke kota Pekanbaru.

3. Namun apabila dilihat secara bersama-sama faktor pembangunan kota, lokasi kota, kesempatan kerja, situasi keamanan kota dan juga budaya merantau memberikan pengaruh signifikan terhadap motivasi pendatang ke Kota Pekanbaru $(0,01<$ $0,05)$

4. Faktor kesempatan kerja memberikan pengaruh negatif $(-0,069)$ terhadap motivasi pendatang ke kota Pekanbaru, dimana semakin besar kesempatan kerja maka akan semakin menekan motivasi untuk datang ke kota Pekanbaru. Hal ini dikarenakan dengan luasnya kesempatan kerja yang ada di Kota Pekanbaru maka tingkat persaingan akan semakin tinggi, kondisi ini menyurutkan ketertarikan pendatang untuk datang dan pendatang akan mencari tempat yang kurang persaingannya.

5. Faktor pembangunan kota $(0,22)$, lokasi kota $(0,002)$, situasi keamanan $(0,05)$ dan budaya merantau $(0,54)$ memberikan pengaruh positif terhadap motivasi pendatang untuk datang ke kota Pekanbaru dimana semakin pesat pembangunan kota, semakin strategis lokasi kota, semakin aman situasi kota dan semakin merakyat budaya merantau maka semakin termotivasi pendatang untuk datang ke kota tersebut.

6. $43,6 \%$ motivasi pendatang dipengaruhi oleh pembangunan kota, lokasi kota, kesempatan kerja, situasi keamanan dan budaya merantau dan sisanya $56,7 \%$ lainnya dipengaruhi oleh faktor lain.

\section{PEMBAHASAN}

Pendatang merupakan masalah tersendiri bagi suatu kota yang sedang membangun. Di satu sisi pendatang memberikan ketersediaan tenaga kerja dalam rangka pelaksanaan pembangunan. Namun jika sudah berlebih pendatang menjadi masalah dan hal ini apabila dikaitkan dengan masalah persaingan dengan tenaga kerja lokal yang menjadi masalah tersendiri.

Sebagaimana yang terjadi pada persaingan yang ketat antara tenaga kerja lokal dan non lokal dari hasil penelitian Fatkhurahman (2008) yang mengkasuskan penelitian pada kesempatan kerja yang berada di Mall. Hasil penelitian menunjukkan bahwa dominasi tenaga kerja yang bekerja pada Mall adalah tenaga kerja non lokal. Walaupun ditemukan banyak penyebab terjadinya rendahnya persaingan tenaga kerja lokal tersebut.

Namun dalam konsep ini menjadi suatu masalah yang dihadapi oleh pemerintah Kota Pekanbaru dalam rangka mengatasi masalah pengangguran di daerah ini. Hasil penelitian ini menunjukkan bahwa motivasi pendatang ke kota Pekanbaru dalam kategori tinggi (77\%). Hal ini menunjukkan bahwa pendatang memiliki semangat yang tinggi untuk datang ke kota Pekanbaru.

Motivasi yang tinggi ini ternyata dipengaruhi oleh faktor budaya merantau masyarakat yang dominan perantau berasal dari daerah sumatera barat (Sumbar) khusus temuan di daerah panam (kecamatan Tampan).

Apabila dilihat dari budaya merantau menjadi satu fenomena tersendiri dimana masyarakat pendatang yang dominan masyarakat minang memiliki budaya merantau dan sudah mendarah daging begitu anak mereka sudah berakal diperintahkan untuk merantau.

Selain itu juga merantau dijadikan ajang untuk merubah nasib, dimana nasib perantau kebanyakan lebih beruntung dibandingkan dengan mereka yang tidak merantau. 
Temuan yang diperoleh dari penelitian ini menunjukkan penilaian terhadap kondisi Kota Pekanbaru seperti tentang pembangunan kota diamana pembangunan kota adalah kondisi perubahan yang terjadi dalam sebuah kota dalam hal ini adalah pembangunan ekonomi, pembangunan pendidikan, pembangunan kesehatan, pembangunan sosial, budaya dan politik di kota Pekanbaru.

Penilaian yang dilakukan dalam pembangunan kota Pekanbaru adalah dengan penilaian yang dilakukan pendatang terhadap keberadaan kota Pekanbaru di mata pendatang. Standarnya adalah baik (berkembang pesat (3)), sedang (berkembang (2)) dan kurang (stagnan (1)) hasil penelitian menunjukkan pembangunan kota Pekanbaru menurut pendatang adalah pesat $(77 \%)$.

Kemudian berkaitan dengan masalah lokasi kota dimana lokasi kota adalah letak dimana kota Pekanbaru berada yang lokasi ini dapat membuat pendatang tertartarik untuk mendatangi kota Pekanbaru. Lokasi ini dinilai oleh pendatang dengan memberikan penilaian baik (strategis (1)), sedang (cukup strategis (2)) kurang (kurang strategis (1)) dengan penilaian terhadap lokasi kota Pekanbaru menurut pendatang cukup strategis $(77 \%)$. Selain itu berkaitan dengan kesempatan kerja adalah peluang kerja yang diberikan kepada tenaga kerja untuk bekerja dalam sebuah kota, dimana kesempatan kerja ini dinilai oleh pendatang dengan memberikan penilaian baik (luas (1)), sedang (cukup (2)) kurang (sempit (1)). Hasil penelitian menunjukkan kesempatan kerja yang ada di Kota Pekanbaru tinggi (80\%). Situasi keamanan kota adalah kondisi dimana kota Pekanbaru yang ancaman bencana alam dan keamanan fisik. Situasi ini dinilai oleh pendatang dengan memberikan penilaian baik (aman (1)), sedang (cukup aman (2)) kurang (kurang aman (1)). Hasil penelitian menunjukkan bahwa situasi keamanan aman $(60 \%)$.

Hasil penelitian tersebut setelah dilakukan perhitungan pengaruh antar variabel ditemukan bahwa: faktor budaya merantau menjadi faktor yang berpengaruh signifikan mempengaruhi motivasi pendatang ke kota Pekanbaru $(0,007$ < $0,05)$. Sedangkan faktor pembangunan kota $(0,241>0,05)$, faktor lokasi kota $(0,987>$ $0,05)$, kesempatan kerja $(0,702>0,05)$ dan situasi keamanan kota $(0,707>0,05)$ memberikan pengaruh tidak signifikan terhadap motivasi pendatang untuk datang ke kota Pekanbaru.

Namun apabila dilihat secara bersama-sama faktor pembangunan kota, lokasi kota, kesempatan kerja, situasi keamanan kota dan juga budaya merantau memberikan pengaruh signifikan terhadap motivasi pendatang ke Kota Pekanbaru $(0,01<0,05)$.

Faktor kesempatan kerja memberikan pengaruh negatif $(-0,069)$ terhadap motivasi pendatang ke kota Pekanbaru, dimana semakin besar kesempatan kerja maka akan semakin menekan motivasi untuk datang ke kota Pekanbaru. Hal ini dikarenakan dengan luasnya kesempatan kerja yang ada di Kota Pekanbaru maka tingkat persaingan akan semakin tinggi, kondisi ini menyurutkan ketertarikan pendatang untuk datang dan pendatang akan mencari tempat yang kurang persaingannya.

Faktor pembangunan kota $(0,22)$, lokasi kota $(0,002)$, situasi keamanan $(0,05)$ dan budaya merantau $(0,54)$ memberikan pengaruh positif terhadap motivasi pendatang untuk datang ke kota Pekanbaru dimana semakin pesat pembangunan kota, semakin strategis lokasi kota, semakin aman situasi kota dan semakin merakyat budaya merantau maka semakin termotivasi pendatang untuk datang ke kota tersebut. 43,6\% motivasi pendatang dipengaruhi oleh pembangunan kota, lokasi kota, kesempatan kerja, situasi keamanan dan budaya merantau dan sisanya $56,7 \%$ lainnya dipengaruhi oleh faktor lain.

Pembangunan kota yang pesat, lokasi kota yang strategis, situasi kota yang aman mendorong pendatang untuk datang ke kota Pekanbaru. Kondisi ini dapat menyebabkan berbagai persoalan baik sosial maupun ekonomi serta lingkungan. 
Terjadinya persaingan tenaga kerja, terjadinya pengangguran, terjadinya eksploitasi tanah untuk perumahan dan lain sebagainya.

Hal ini sejalan dengan apa yang disampaikan (Suparmoko, 2008) bahwa ada hubungan antara pertumbuhan penduduk yang tidak terkendali menimbulkan banyak masalah sosial ekonomi serta lingkungan.

\section{SIMPULAN}

Berdasarkan hasil penelitian di atas, maka dapat ditarik beberapa kesimpulan antara lain:

1. Ternyata yang memotivasi pendatang untuk datang ke kota Pekanbaru, khususnya daerah panam (kecamatan Tampan) adalah karena faktor budaya merantau, diikuti oleh faktor pembangunan kota Pekanbaru yang pesat, kemudian karena situasi keamanan kota Pekanbaru dan juga karena kesempatan kerja yang tersedia.

2. Ternyata kesempatan kerja dapat menyurutkan keinginan pendatang untuk datang ke kota Pekanbaru (khususnya daerah panam), karena dengan besarnya kesempatan kerja maka persaingan mendapatkan pekerjaan akan semakin ketat. Kondisi ini yang tidak diinginkan oleh pendatang dengan modal pendidikan dan keahlian yang serba pas-pasan.

Dari kesimpulan di atas, maka dapat diberikan beberapa saran dalam rangka mengendalikan pendatang ke kota Pekanbaru, antara lain:

1. Kebijakan makro ekonomi dalam rangka mengatasi masalah pengangguran lokal dalam rangka otonomi daerah diarahkan lebih meningkatkan kesempatan kerja di daerah yaitu dengan mempromosikan peluang investasi di daerah yang diharapkan dapat menyurutkan pendatang yang untuk menambah angka pengangguran di daerah ini yang bermodalkan pendidikan dan keahlian yang pas-pasan.

2. Tingkat daya saing tenaga kerja lokal dalam rangka merebut pasar kerja di daerah dengan memberikan pendidikan dan keahlian melalui kebijakan pendidikan yang bermutu.

\section{DAFTAR RUJUKAN}

Aloewie, F, Chepy, 2006, Situasi tenaga kerja dan kesempatan kerja di Indoensia, Depnakertrans, Jakarta.

Kartomo Wirosuhardjo, 1981, Dasar-Dasar Demografi, Lembaga Demografi, FE-UI, Jakarta.

Mulyadi, 2003, Ekonomi Sumber Daya Manusia, PT Raja Grafindo Persada, Jakarta.

Payaman. J, 1998, Kebyaksanaan Ketenagakerjaan, Prisma, Jakarta.

Sumitro, Djojohadikusumo, 1994. Perkembangan Pemikiran Ekonomi, Dasar Teori Pertumbuhan dan Ekonomi Pembangunan, LP3ES, Jakarta

Widodo, Suseno, Triyanto, 1990, Indikator Ekonomi, Dasar Perhitungan Perekonomiaan Indonesia, Kanisius, Yogyakarta

Sulistiyani, Ambar Teguh \& Rosidah, 2003, Manajemen Sumber Daya Manusia, Konsep, Teori dan Pengembangan dalam Konteks Organisasi Publik.

Suparmoko, 2008, Ekonomi Sumber Daya Alam dan Lingkungan Hidup, FEUGM, Yogyakarta.

Todaro, M.P. 2000. Pembangunan Ekonomi di Dunia Ketiga, diterjemahkan oleh Haris Munandar. Bumi Aksara, Jakarta. 
Ubaedy, An, 2007, Kompetensi Kunci dalam Berkompetisi, Career, Business \& Life, Bee Media, Jakarta.

Fatkhurahman, 2008, Daya Saing Tenaga Kerja Lokal pada Mall di Kota Pekanbaru (Jurnal Eko \& Bisnis, Volume 1 Nomor 1)

Perda Kota Pekanbaru No. 4 Tahun 2002 tentang Penempatan Tenaga Kerja Lokal 